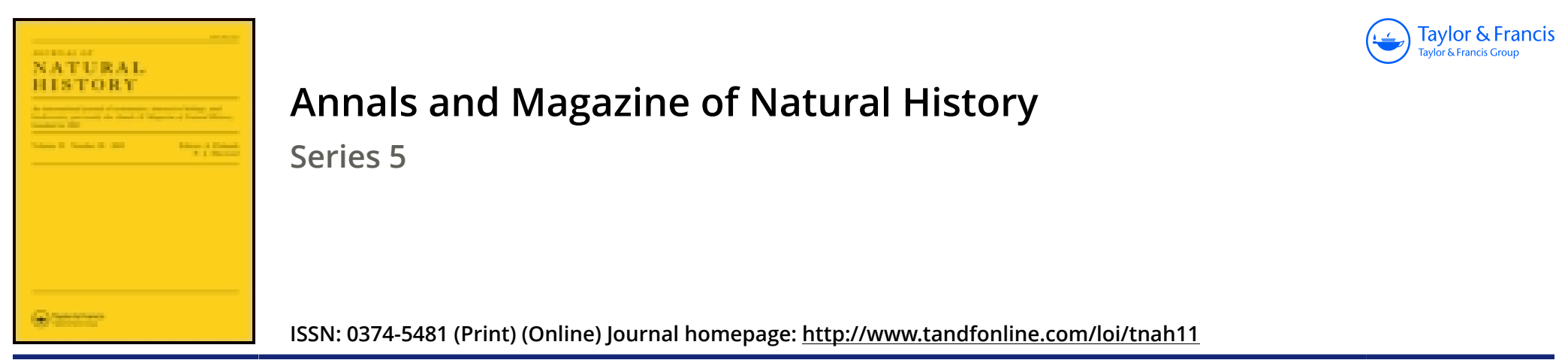

\title{
Dutch Mollusca
}

\section{J. Gwyn Jeffreys LL.D. F.R.S.}

To cite this article: J. Gwyn Jeffreys LL.D. F.R.S. (1881) Dutch Mollusca, Annals and Magazine of Natural History, 8:48, 446-448, DOI: 10.1080/00222938109487489

To link to this article: http://dx.doi.org/10.1080/00222938109487489

$$
\text { 册 Published online: } 09 \text { Oct } 2009 .
$$

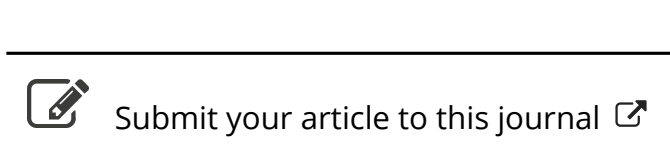

\footnotetext{
Q View related articles $\sqsubset$
} 
justifies the following remarks of Mr. Darwin :-“"When we behold a wide turf-covered expanse, we should remember that its smoothness, on which so much of its beanty depends, is mainly due to all the inequalities having been slowly levelled by worms. It is a marvellous reflection that the whole of the superficial mould over any such expanse has passed, and will again pass, every few years through the bodies of worms." .Large stones lying on the surface of grass-land become gradually imbedded, partly by the raising of the surface and partly by the undermining action of worms; and the same influences have been at work, as the author well shows, in the covering up with a layer of mould of the remains of ancient buildings.

The quantity of earth moved in this way is enormous, and such as to surprise those whose minds are not already familiar with the vast effects that are produced in nature by the long-continued working of minute agencies. By collecting, drying, and weighing the worm-casts over a given space of ground $\mathrm{Mr}$. Darwin is enabled, at least approximately, to determine the quantity of soil brought to the surface by worms; and he finds that in many parts of England this amounts to about ten tons per acre annually. Two of his calculations, however, give a much larger amount, namely 16.1 and 18.12 tons per acre. These larger quantities, when corrected, would prodnce a layer of about $1 \frac{1}{2}$ inch spread over the whole surface in ten years. This, of course, does not represent increase of thickness, but only the rate of transfer of the underlying monld to the surface.

This notice has extended to such a length that we must bring it somowhat abruptly to a close, merely remarking in conclusion that, besides their influence upon the formation of mould, Mr. Darwin ascribes to earthworms under certain conditions an important action in aid of the phenomena of denudation, as their castings, when present on the surface, will be peculiarly liable to be washed away by heavy rains, and even in dry weather they will break up into small pellets which may easily be transported by the wind. It is hardly necessary to say further that for the better exposition of the main subject of his book Mr. Darwin thoroughly describes the structure and habits of worms, and dwells especially upon their senses and mental qualities. His book is a most interesting and attractive one, and its teaching of the importance in nature of what are apparently the most contemptible of agents will furnish an excellent lesson to many besides the reading section of the general public.

\section{MISCELLANEOUS.}

Dutch Mollusca. By J. Gwxn Jefreers, LL.D., F.R.S.

WHILE passing a short time in Holland, immediately after sustaining the greatest calamity which can befall a man (the death of a longloved wife), I spent a day at Scheveningen, a favourite sea-side 
resort near the Hague, and I made a note of the shells that had been thrown up on the sands. The season being over, I had the beach to myself. As I am not aware that any list of the Mollusca from the Dutch coast has been published since the work of Dr. Herklots, now nearly twenty years ago, I subjoin the names of those species which I noticed during my solitary ramble. Although all of these species are common in the North Sea, one of them at least (Montacuta bidentata) is not mentioned in the above work on the Mollusea of the Netherlands; and the list may be useful to give the modern nomenclature.

\section{CONCHIFERA.}

Ostrea edulis, Linné.

Pecten varius, $L$.

Mytilus edulis, $L$.

Montacuta bidentata, Montagu.

Cardium edule, $L$.

Tellina balthica, $L$. Larger than British specimens, and thrice the size of those from the Baltic.

- tenuis, Da Costa.

- fabula, Gronovius.

Donax vittatus, Da Costa.

Mactra solida, $L$., and var. truncata.

— subtruncata, Da Costa.

- stultorum, $L$. Very large.

Lutraria elliptica, Lamarck.
Scrobicularia alba, W. Wood.

- piperata, Bellonius.

Solen ensis, $L$.

- siliqua, $L$.

Mya truncata, $L$.

Pholas candida, $\boldsymbol{L}$.

\section{Gastropoda.}

Trochus zizyphinus, Linné.

Littorina obtusata, $L$.

- litorea, $L$.

Scalaria communis, Lamarck.

Natica catena, Da Costa.

— Alderi, Forbes.

Buccinum undatum, $L$.

Nassa reticulata, $L$.

This list gives a total of twenty-seven species, viz. nineteen bivalves and eight univalves. All of them inhabit sand except the first-named three species of univalves, which inhabit rocky places.

In the great wood between the Hague and Scheveningen I obserred a few land and freshwater shells, viz.:-Zonites purus, Alder; Z. radiatulus, Ald.; Z. crystallinus, Müller; Z. fulvus, Müll. ; Helix pulchella, Müll., and var. costata; Cochlicopa lubrica, Müll., var. lubricö̈des; Carychium minimum, Müll.; and Unio tumidus, Philippson.

These lists could easily be quadrupled by examining the refuse from fishermen's boats and spending more time than I had to spare.

41 Seymour Street, 7 Nov, 1881.

An Abbreviated Metamorphosis in Alpheus heterochelis. By A. S. Packard, Jun.

This species and Alpheus minus, Say, are very abundant, living in the larger excurrent orifices of the large sponges which exist from the depth of one or two feet or more to deeper water, at Key West, Florida. A. minus, however, is far more abundant than the larger species. I found several of A. heterochelis with far advanced embryos in the winter of 1869-70, and on removing the embryonic 
zoëa from the egg, was interested to find that the larva was of a form much moro advanced than in the zö̈a of other Anomura described and figured by Fritz Mïller in his suggestive work entitled "Facts for Darwin." Indeed the metamorphosis appears to be abbreviated; and the larra, on hatching, closely approximates the form of the adult, as in the case of the development of the lobster, the crayfish, and of Palcemon adspersus and Eriphia spinifrons (the three latter observed by lathle). The eyes were dereloped on very short peduncles, being almost sessile. The embryo was near the time of hatching, though the yolk was not entirely absorbed. The two pairs of antennæ were well developed and hung down behind the large claws; the five pairs of legs were well developed, the joints distinct, and the first pair were about twice as thick as the others, the claws rather large, but not so disproportionately so as in the adult form, but as much so as in the larva in the second stage of the lobster, figured by Prof. Smith. The eyes were large, but nearly sessile. The abdomen was broad and flat, spatulate at the end much as in the adult; there were five pairs of abdominal feet or swimmerets, each with an endopodite and exopodite, like those secn in the second larval stage of the lobster.

It thus appears that Alpheus heterochelis hatches in a stage more advanced than the first larval stage of the lobster. Unfortunately the specimens, though carefully preserved for several years, finally got misplaced; so that it is not possible for us to give a more detailed description of the young at the time of birth.-Amer. Nat., Oct. 1881.

Observations on the Rotifera of the Genus Melicerta. Вy М. JoLmet.

The observations here summarized were made upon two species of Melicerta, namely Melicerta ringens and an allied species distinguished by the presence of a long thread that fixes it in its sheath. With the exception of a few details, all that applies to the one applies to the other.

Nervous System.--Several authors, following Huxley, have stated that the ganglion of the Melicertina is situated near the mouth, and consequently 'at the surface of the body opposite to the anus. This would be the reverse of what cxists in all Rotatoria. In reality, what these observers have taken for the ganglion is a gland, both in its structure and in its situation and functions. The true nervous centre is on the opposite side, on the dorsal surface of the pharyux. It consists of a group of large cells of very characteristic torm, and furnished with a voluminous nucleus. Several similar cells are arranged by the side of the former, and extend in different directions. This centre a good deul resembles that described by Leydig in the genus Lacinularia. It is not voluminous; and I think that the comparatively enormous ganglia that have been described in several Rotatoria are glands, and that the true nerrous centre is still to be sought.

In any case, we see that the anomaly created for the Melicertina 